\title{
Job Insecurity, Work Engagement and Job Performance of Employees in Flexible Working Arrangement: Exploring the Mediating Role of Psychological Well-Being
}

\author{
Uliyatun Nikmah ${ }^{1 *}$, Fanny Martdianty ${ }^{2}$ \\ 1,2 Universitas Indonesia, Jawa Barat, Indonesia \\ *Corresponding author. Email: nikmahaulia@gmail.com
}

\begin{abstract}
Organizations and employees must be alert and adaptive in facing volatile, uncertain, complex, and ambiguous environment. Uncertainty in the workplace as well as the workforce can pose a threat to performance. This study aims to analyse the effect of mediating role of psychological well-being in explaining the impact of job insecurity towards work engagement and job performance of employees working in a flexible work arrangement. This study used Structural Equation Modelling (SEM) in the analysis. Study data were collected from 206 employees across various sectors in Indonesia. The findings showed that psychological well-being was found to be fully mediating the impact of job insecurity towards employees' work engagement and job performance. Future directions highlight the importance of providing job security to employees and maintaining employees' psychological well-being to boost engagement and performance thus provides benefits to the organizations.
\end{abstract}

Keywords: Job insecurity, Psychological well-being, Work engagement, Job performance.

\section{INTRODUCTION}

Transformations in the last few decades, such as in technological, economic, and political aspects, have impacted the dynamics of work. In addition to decreasing union strength, job stability and predictability are now increasingly being replaced by job insecurity in line with companies' policies to reduce workers, outsource, and increase demand for efficiency [1].

Today's organizations must always be alert and adaptive in facing environment in volatility, uncertainty, complexity, and ambiguity (VUCA), such as external crises. It can create uncertainty in the workplace as well as the workforce and pose a direct threat to organizational performance and its continuity. The Covid-19 pandemic caused by the novel coronavirus which emerged at the end of 2019 makes organizations suddenly have to navigate businesses in unprecedented conditions and find solutions to the challenges that arise [2].

The International Labour Organization (ILO) [3] predicts a significant reduction in working hours in the second quarter of 2020 by $14 \%$ worldwide or the equivalent of 400 million full-time workers. This forecast was also announced along with projections of higher year-end unemployment rate. The Covid-19 pandemic can lead to involuntary layoffs that threaten the security of workers in various career stages and sectors [3].

The pandemic has brought many changes in work environment such as limited human contact to reduce the spread of the virus. As a result, many organizations change the habits of their employees from working in the office to remote work or work from home (WFH) [4]. WFH program, which was very popular during the pandemic, is part of the flexible work arrangements (FWA) concept and has become commonplace in the world of work and urban planning [5]. FWA is defined by [6] as a job arrangement that allows employees to adjust the amount, time, and location of their work.

This health crisis creates many challenges for the economy and jobs in general. Organizational performance, an aggregate of individual employees' performance [7] in this pandemic is encountering the 
impact, along with various aspects of individual and companies work. Economic and employment recessions, rising unemployment rates, and limited-time employment contracts further increase job insecurity [3]. Adding to the mix that many employees cannot go to work normally may change their perceptions of job security and well-being.

Job insecurity is defined as the perception of threat of losing current job in the near future [8]. Various studies have documented the negative effects of job insecurity [1], [9]-[11], among others, it can reduce work attitudes such as job satisfaction and commitment, health, physical and mental well-being, undermined performance, creativity, and adaptability [9], [12]-[14], and also attachment to work [10], [15].

The literature shows that the effect of job insecurity on job performance is still developing, with weaker evidence compared to other variables but going in the consistent negative direction [7]. Several studies have shown the direction of a positive relationship such as [13] which makes research on the relationship between these two variables interesting to be explored further.

Psychological well-being, aside from being impacted by job insecurity, has a positive effect on work engagement, which shows employees involvement in their work [16] and has a positive effect on employee performance [17], [18]. When psychological well-being is perceived to be unfavourable, as a consequence it will reduce employee involvement in their work and their performance. This paper will be presented in a structure that include introduction, literature review, method, results, discussions, and conclusion.

\subsection{Job Insecurity}

Conservation of Resources (COR) theory by [19] is considered to be able to explain the causes of job insecurity and why job insecurity is often associated with negative outcomes [19]. It explains that individuals are motivated to acquire, build, and maintain things that are considered as valuable resources [19]. One of them is a stable job that can facilitate individuals to obtain other resources both in material and non-material forms (income, shelter, food, clothing, social status, honour and so on). When these resources are lost or threatened with loss, it can cause psychological pressure [20].

Research related to the stress perspective through the COR theory has been analysed through various studies [21]. Job insecurity is found to be a stressor or antecedent to various job outcomes [1], [8], [10], [14]. A meta-analysis involving 252 samples found that job insecurity has a significant relationship with 56 outcomes [10]. The possible consequences of job insecurity that occur at the individual level in the short term (work attitude such as job satisfaction) and the long term (health and well-being) and the organizational level in the short term (organizational attitudes such as commitment) and the long term (work-related behaviour such as individual performance) [14].

Previous research has supported that job insecurity can lead to reduced employee well-being [9], [14], [19], [22]. This well-being can include general health, psychological health, namely emotional and mental health, physical health, to musculoskeletal disorders). Vulnerable economic conditions such as insecurity in the labour market and income can produce a more severe reaction to job insecurity [1].

Job insecurity was also found to have a negative impact on job performance [9], [10], [22], especially for employees at the lower-level management level of the company. Research by [20] adopting [21]'s study analysed the effect of job insecurity on performance which has a natural $U$ shape on employees in the United States and was successful in confirming it. This occurs when an individual's assessment of performance decreases when the job insecurity level is moderate, and increases when the job insecurity level is low and high so that it forms an inverted-U.

\subsection{Psychological Well-Being}

Psychological well-being is defined as the overall effectiveness of an individual's psychological functioning [18]. It is a positive mental health condition for employees. Several factors such as stress, anxiety, depression and post-traumatic stress disorder can affect the mental health of employees. Psychological wellbeing was found to be significantly negatively employee performance [17], [18]. When psychological well-being is felt to be unfavourable, it will reduce employee performance as a consequence.

Psychological well-being is related to individual happiness and experiences. Happy employee is believed to be more productive employee [17]. The component of well-being happiness itself is an experience of pleasure that can balance negative and positive thoughts and feelings. Thus, psychological well-being focuses on attitudes and behaviours.

\section{Work Engagement}

Work engagement is defined as positive workrelated thoughts characterized by vigour, dedication, and absorption [23]. Vigour is described as high energy and resilience, and a desire to invest effort in one's work, and persistence even when faced with difficulties. Dedication is described as significant, enthusiastic, inspirational, proud, and challenging feelings; and absorption is characterized when a person is immersed in a job, that time passes quickly and is difficult to leave work. Meanwhile, the factor structure of work engagement was suggested to be determined from data of each study [24].

Engagement refers to a more persistent and pervasive cognitive-affective state that does not focus 
on a specific object, event, individual or behaviour. Engagement is also known to be the opposite of burnout [23]. Several antecedents such as job insecurity [15], [25], and psychological well-being [16] are known to affect work engagement [14].

The level of positive affective or happiness in the study was found to reduce the negative impact of job insecurity [25]. One of the main job outcomes found to be influenced by work engagement is individual job performance [14], [15].

\subsection{Job Performance}

Performance is a behaviour that contributes directly to the technical core of the organization and includes activities commonly known as part of the employee's job [26]. Job performance or the performance of individual employees who work in a company will contribute in an aggregate manner to company performance [7]. Many studies have documented the negative effects of job insecurity [1], [9]-[11], among others, reducing work attitudes such as job satisfaction and commitment, to disturbing employee welfare and health.

The literature studying the effect of job insecurity on job performance is still developing, with weaker evidence compared to other variables but going in the negative direction leading to a decrease in employee performance [7], [14]. These findings were generally similar in both cross-sectional and longitudinal studies and regardless of ratter whether by individual or supervisor. Overall, the relationship between job insecurity and performance is negative and weaker in countries with strong social welfare protection [14].

A few but limited studies have shown a positive direction of the relationship [13], [27]. A reason that can explain this is that when employees feel high job insecurity or faced with the potential for loss of valuable resources, according to COR theory [9], this can encourage higher performance achievement, because they believe that hard work will protect them from being expelled from work [7].

In summary, this study will present the analysis of two main hypotheses as follows:

H1: Psychological well-being mediates the relationship between job insecurity and work engagement

$\mathrm{H} 2$ : Psychological well-being mediates the relationship between job insecurity and job performance.

\section{METHOD}

\subsection{Sample}

This study collected data from online questionnaires self-administered by respondents. From 234 people who participated, 28 did not fulfil respondents' criteria such as working less than 1 year in the current company or currently do not perform work in FWA, thus leaving sample of $\mathrm{n}=206$ employed workers. The representation of female and male respondents is almost the same, majority of their employment status is permanent $(72 \%)$, and their tenure is 5 years 3 months in average. Respondents occupy positions ranging from staff to executive such as general manager.

Majority of respondents have bachelor's degree (67\%), followed by those who completed master (23\%), diploma $(7 \%)$, and high school degree $(2.5 \%)$. $60 \%$ of respondents were married, while $39 \%$ were single. $46 \%$ and $76 \%$ of respondents were in FWA based on time and location flexibility respectively at the time of study, where quite a number respondents performed both. The sectors where respondents worked vary including telecommunications, public services, education, finance $\&$ banking, trade and general services, manufacture, oil and gas, transportation, and other sectors.

\subsection{Measures}

Respondents had to indicate variables in 7-point responses from strongly disagree to strongly agree, and in frequency from never to always in responding two variables namely psychological well-being and work engagement.

Psychological Well-Being was measured using the 12-items General Health Questionnaire (GHQ-12) developed by Goldberg and Williams (1988) which was used in [28]. Items 7-12 were reversed [21]. A high score indicates a high level of employees' psychological well-being.

Job insecurity was measured through the Job Insecurity Scale which consists of 4 items from [29] who had evaluated its psychometric characteristics in several countries. This scale is the measurement most widely used in research on job insecurity [29].

Work engagement was measured using 9 items from the Utrecht Work Engagement Scale (UWES), a widely used instrument which has been psychometrically tested in various countries and research samples [23]. Work engagement is measured through one factor structure as suggested by [24] and the result from factor analysis in this study.

Job performance was measured using a 5-items proficiency scale on individual assignments based on [30]. Self-reported job performance assessment has been used extensively in research and has been shown to have good reliability [22], [30]. 


\section{RESULTS AND DISCUSSION}

Structural Equation Modelling (LISREL 8.80) was used to test the model fit and hypotheses. Convergent validity is indicated by significant high factor loadings with estimates $\geqslant 0.50$ [31]. Outputs showed satisfactory results with the exception of three indicators, namely item 2 and 3 of psychological well-being and item 8 of work engagement, thus they were excluded from further analysis. Construct reliability (CR) of 0.70 or above and an average variance extracted (AVE) of more than 0.50 suggest good reliability [31]. All variables met the criteria (Table 1), aside from AVE of psychological well-being with score 0.41 . VE results $<0.50$ are still acceptable because they are considered to have no fatal impact, and the results are acceptable with CR showing good result [32].

Several measures of approximation were employed to describe the strength of the model's predictions. Each absolute and incremental index which shows good fit $(>0.90)$ already provided sufficient information in evaluating a model [30]. Absolute fit measures of $\chi^{2}=$ 704.85 ( $\mathrm{p}$-value $=0.00)$; df $=314$; Root Mean Square Error of Approximation (RMSEA) $=0.078$; and the Goodness-of-Fit Index (GFI) $=0.80$; and incremental fit measures showed Normed Fit Index (NFI), Comparative Fit Index (CFI), and Incremental Fit Index (IFI) at 0.94; 0.96; and 0.96 respectively, which indicated that the model is fit.

The structural model shown in Figure 1 showed that job insecurity negatively affects psychological well- being $(\beta=-0.55 ; \mathrm{p}<0.01)$, meanwhile psychological well-being positively affects work engagement $(\beta=$ $0.51 ; \mathrm{p}<0.01)$ and job performance $(\beta=0.61 ; \mathrm{p}<$ $0.01)$. The significance of mediation role was also tested, and the results showed significant statistics of psychological well-being in fully mediating the impact of job insecurity towards work engagement $(\beta$ indirect $=$ $-0.281 ; \mathrm{p}<0.01)$. and job performance $(\beta$ indirect $=-$ $0.337 ; \mathrm{p}<0.01)$.

Studying perception of employees who are implementing FWA is highly interesting, considering that they possess distinct characteristics that differentiate them from those in conventional arrangement. They can have varied working hours or working from different places which may expose them to high technology usage, less direct monitoring from supervisor, more power to control work and life, facing dynamic social norm [5], aside from other benefits and challenges. Analysis of employees' experience who are implementing FWA from Table 1 can be summarized that they experience quite low job insecurity, and they perceive their psychological well-being, work engagement, and job performance to be quite high.

The study especially confirmed the negative impact of job insecurity towards job performance [7] and work engagement through the mediation of psychological well-being thus added to the growing body of research that studies the relationship. Organizations should pay great attention to employees' psychological well-being to improve employees' performance [17] and engagement [16] that contribute to organization's performance and sustainability.

Table 1. Descriptive statistics

\begin{tabular}{|l|c|c|c|c|c|c|}
\hline \multirow{2}{*}{\multicolumn{1}{c|}{ Variable }} & \multirow{2}{*}{ Mean } & \multirow{2}{*}{ Std. Dev } & \multicolumn{4}{c|}{ Correlation } \\
\cline { 4 - 7 } & & & $\mathbf{1}$ & $\mathbf{2}$ & $\mathbf{3}$ & $\mathbf{4}$ \\
\hline Job Insecurity & 2.582 & 1.615 & 0.874 & & & \\
\hline Psychological Well-being & 5.246 & 1.381 & $-0.550^{* *}$ & 0.875 & & \\
\hline Work engagement & 5.426 & 1.231 & $-0.351^{* *}$ & $0.548^{* *}$ & 0.935 & \\
\hline Job performance & 5.852 & 0.957 & $-0.466^{* *}$ & $0.686^{* *}$ & $0.382^{* *}$ & 0.894 \\
\hline
\end{tabular}

**Correlation is significant at the 0.05 level (2-tailed)

Score in diagonal columns showed CR as reliability criteria

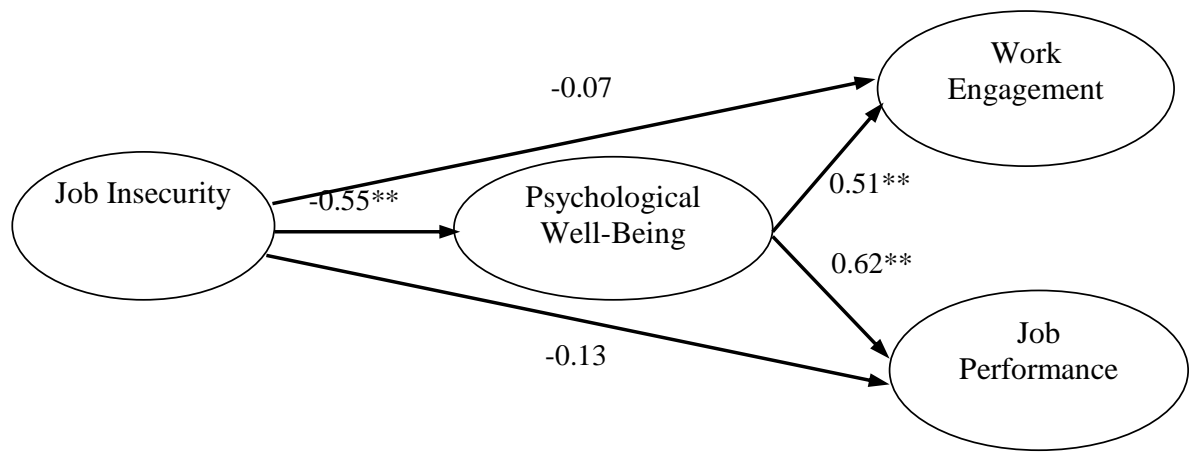

Figure 1. The hypothesized structural model result

While implementing FWA practices, organizations should foster a healthy working environment towards employees as they are able to work in flexible schedule and or they are not coming to the office every day. 
Operating in uncertain times, it serves as a challenge for organizations to ensure high levels of job security to the employees, even more so in developing country such as Indonesia with the growing social welfare [33]. Support from all parties is needed to build employees' resilience in facing uncertainties [34].

\section{CONCLUSION}

This study findings showed that the two hypotheses were supported. Psychological well-being was found to be fully mediating the impact of job insecurity towards work engagement and job performance of employees in FWA. FWA practice in the workforce may be even more widely implemented in the near future. So, it is important for organizations to understand its association with job outcomes particularly for organizations that embrace the practice.

This research has several recommendations that can be addressed by future research. This study was carried out during Covid-19 pandemic which may play a role in respondents' perceptions towards specific variables. Furthermore, all variables in this study were assessed using self-report, which may be exposed to method bias [14]. Future research may consider involving another source's response in measuring them, for example supervisor's in rating job performance. The respondents cover a wide job sector, where specific sectors may portray different perceptions. Analysing other variables can also provide valuable insights, such as the relationship of work and family domain or role of technology in similar context. This study was crosssectional in nature that future research can carry out a longitudinal study in particular to analyse relationship between variables which may change over time. Highlighting the difference between sample characteristics such as based on gender, employment status, and so on can also bring new perspectives.

\section{ACKNOWLEDGMENTS}

The authors would like to thank Indonesia Endowment Fund for Education (LPDP) for the sponsorship. This work would not have been possible without the financial support of LPDP.

\section{REFERENCES}

[1] M. K. Shoss, "Job insecurity: An integrative review and agenda for future research," $J$. Manage., 43(6), pp. 1911-1939, 2017.

[2] J. B. Carnevale and I. Hatak, "Employee adjustment and well-being in the era of COVID-19: Implications for human resource management," $J$. Bus. Res., 116(May), pp. 183-187, 2020.
[3] ILO, "COVID-19 and the world of work: Updated estimates and analysis," ILO Monit., pp. 1-22, 2020.

[4] A. A. Adalja, E. Toner, and T. V. Inglesby, "Priorities for the US Health Community Responding to COVID-19," JAMA - J. Am. Med. Assoc., 323(14), pp. 1343-1344, 2020.

[5] O. Mungkasa, "Bekerja dari rumah (Working From Home/WFH): Menuju tatanan baru era pandemi COVID 19," J. Perenc. Pembang. Indones. J. Dev. Plan., 4(2), pp. 126-150, 2020.

[6] L. M. De Menezes and C. Kelliher, "Flexible working and performance: A systematic review of the evidence for a business case," Int. J. Manag. Rev., 13(4), pp. 452-474, 2011.

[7] N. De Cuyper, B. Schreurs, H. De Witte, and E. Selenko, "Impact of job insecurity on job performance introduction," Career Dev. Int., 25(3), pp. 221-228, 2020.

[8] T. Vander Elst, N. De Cuyper, E. Baillien, W. Niesen, and H. De Witte, "Perceived control and psychological contract breach as explanations of the relationships between job insecurity, job strain and coping reactions: Towards a theoretical integration," Stress Heal., 32(2), pp. 100-116, 2016.

[9] H. De Witte, J. Pienaar, and N. De Cuyper, "Review of 30 years of longitudinal studies on the association between job insecurity and health and well-being: Is there causal evidence?," Aust. Psychol., 51(1), pp. 18-31, 2016.

[10] L. Jiang and L. M. Lavaysse, "Cognitive and affective job insecurity: A meta-analysis and a primary study," J. Manage., 44(6), pp. 2307-2342, 2018.

[11] C. Lee, G. H. Huang, and S. J. Ashford, "Job insecurity and the changing workplace: Recent developments and the future trends in job insecurity research," Annu. Rev. Organ. Psychol. Organ. Behav., 5(November 2017), pp. 335-359, 2018.

[12] G. H. L. Cheng and D. K. S. Chan, "Who suffers more from job insecurity? A meta-analytic review," Appl. Psychol., 57(2), pp. 272-303, 2008.

[13] T. M. Probst, S. M. Stewart, M. L. Gruys, and B. W. Tierney, "Productivity, counterproductive and creativity: The ups and downs of job insecurity," J. Occup. Organ. Psychol., 80(3), pp. 479-497, 2007.

[14] M. Sverke, J. Hellgren, and K. Näswall, "No security: A meta-analysis and review of job 
insecurity and its consequences," J. Occup. Health Psychol., 7(3), pp. 242-264, 2002.

[15] H. J. Wang, C. Q. Lu, and O. L. Siu, "Job insecurity and job performance: The moderating role of organizational justice and the mediating role of work engagement," J. Appl. Psychol., 100(4), pp. 1249-1258, 2015

[16] B. Çankır and S. Şahin, "Psychological well-being and job performance: The mediating role of work engagement," Hitit Üniversitesi Sos. Bilim. Enstitüsü Derg., no. January 2019, 2018.

[17] B. Obrenovic, D. Jianguo, A. Khudaykulov, and M. A. S. Khan, "Work-family conflict impact on psychological safety and psychological well-being: A job performance model," Front. Psychol., 11(March), pp. 1-18, 2020.

[18] T. A. Wright and R. Cropanzano, "Psychological well-being and job satisfaction as predictors of job performance.," J. Occup. Health Psychol., 5(1), pp. 84-94, 2000.

[19] S. E. Hobfoll, "Conservation of resources: A new attempt at conceptualizing stress," Am. Psychol., 44(3), pp. 513-524, 1989.

[20] T. M. Probst, N. J. Gailey, L. Jiang, and S. L. Bohle, "Psychological capital: Buffering the longitudinal curvilinear effects of job insecurity on performance," Saf. Sci., 100, pp. 74-82, 2017.

[21] E. Selenko and B. Batinic, "Job insecurity and the benefits of work," Eur. J. Work Organ. Psychol., 22(6), pp. 725-736, 2013.

[22] E. Selenko, A. Makikangas, and C. B. Stride, "Does job insecurity threaten who you are? Introducing a social identity perspective to explain well-being and performance consequences of job insecurity," J. Organ. Behav., 2017.

[23] W. B. Schaufeli, A. B. Bakker, and M. Salanova, "The measurement of work engagement with a short questionnaire: A cross-national study," Educ. Psychol. Meas., 66(4), pp. 701-716, 2006.

[24] M. Willmer, J. W. Jacobson, and M. Lindberg, "Exploratory and Confirmatory Factor Analysis of the 9-Item Utrecht Work Engagement Scale in a Multi-Occupational Female Sample: A CrossSectional Study," Front. Psychol., vol. 10, p. 2771, 2019
[25] T. Vander Elst, J. Bosman, N. De Cuyper, J. Stouten, and H. De Witte, "Does positive affect buffer the associations between job insecurity and work engagement and psychological distress? A test among South African workers," Appl. Psychol., 62(4), pp. 558-570, 2013.

[26] V. I. Coleman and W. C. Borman, "Investigating the underlying structure of the citizenship performance domain," Hum. Resour. Manag. Rev., 10(1), pp. 25-44, 2000.

[27] T. Staufenbiel and C. J. König, "A model for the effects of job insecurity on performance, turnover intention, and absenteeism," J. Occup. Organ. Psychol., 83(1), pp. 101-117, 2010.

[28] M. D. P. Sánchez-López and V. Dresch, “The 12 item general health questionnaire (GHQ-12): Reliability, external validity and factor structure in the Spanish population," Psicothema, 20(4), pp. 839-843, 2008.

[29] T. Vander Elst, H. De Witte, and N. De Cuyper, "The Job Insecurity Scale: A psychometric evaluation across five European countries," Eur. J. Work Organ. Psychol., 23(3), pp. 364-380, 2014.

[30] L. J. Williams and S. E. Anderson, "Job satisfaction and organizational commitment as predictors of organizational citizenship and in-role behaviors," Journal of Management, 17(3). pp. 601-617, 1991

[31] J. F. Hair, W. C. Black, B. J. Babin, and R. E. Anderson, "Multivariate data analysis: Global edition." 2010.

[32] C. Fornell and D. F. Larcker, "Structural equation models with unobservable variables and measurement error: Algebra and statistics," $J$. Mark. Res., 18, pp. 382-388, 1981.

[33] M. Sverke, L. Låstad, J. Hellgren, A. Richter, and K. Näswall, "A meta-analysis of job insecurity and employee performance: testing temporal aspects, rating source, welfare regime, and union density as moderators," Int. J. Environ. Res. Public Health, 16(14), 2019.

[34] A. Chirumbolo and A. Areni, "Job insecurity influence on job performance and mental health: Testing the moderating effect of the need for closure," Econ. Ind. Democr., 31(2), pp. 195-214, 2010. 